\title{
Mongoloid Dental Complex in the Deciduous Dentition. with Special Reference to the Dentition of the Ainu*
}

\author{
Kazuro HANIHARA \\ Department of Legal Medicine, Sapporo Medical College
}

\begin{abstract}
Although several investigations have been made from different aspects, the origin and the racial history of the Ainu are still remained unsolved. In this connection, it is required to investigate additional characteristics which have not been discussed so far in detail. The present article describes dental characters in the Ainu and gives some idea of morphological pattern of this population. Comparisons with the other populations are also discussed in the light of Mongoloid dental complex. Overall characteristics discussed in this article show that the dentition of the Ainu is close to the Mongoloid populations, especially to the Japanese, in its morphological pattern and this trend is evidently seen in either the deciduous or the permanent dentitions.
\end{abstract}

\section{INTRODUCTION}

At the International Symposium on Dental Morphology held at Fredensborg in Denmark, September 1965, I proposed the term 'Mongoloid Dental Complex' (HAnihara, 1966a). To date the complex refers only to the deciduous dentition and the complex in the permanent dentition is the subject of the future investigation.

Almost a decade ago, LE GROS CLARK (1955) stated that "...anthropologists and human anatomists often tend to focus their attention rather on single characters in their discussion of relationships...", and further he emphasized that phylogenetic or taxonomic

* This article was delivered to the U. S.Japan Conference on Microevolution and Population History of Northern People, held in Sapporo, Japan, August 1966. studies should be based on consideration of the combination of characters and not on the comparison of individual characters one by one. The reason why I venture to propose the term 'dental complex' exists in the same recognition of special importance of the 'total morphological pattern' in CLARK's sense.

During the last few years, I have fortunately had an opportunity to observe the human deciduous teeth from different populations such as the Japanese, American Whites, American Negroes, American Indians, Eskimos and so forth. Based on these data on the crown characters of the deciduous teeth, I have come to realize that some dental characters could be grouped as a character complex which characterizes the Mongoloid populations as a whole.

As is well-known, the Japanese, American Indians and Eskimos are con- 
sidered to have derived from closely related ancestors and so are they called the Mongoloid populations. They represent close similarities each other in their present physical characteristics, particularly in those of the dentition.

The shovel-shaped character in the incisors, for example, has been wellknown for anthropologists as one of the remarkable characters prevailed in the Mongoloids. However, it is hardly reliable to classify a given population in accordance only with frequency or developmental degree of this character. In such a case, certainly other characters such as tooth dimensions, accessory cusps, occlusal patterns, etc., must be regarded in combination.

Recently I reported that there seemed to be two types of the crown characters in respect to the racial differences ( $\mathrm{HA}^{-}$ NIHARA, 1965). One of the types, interrace variable characters, is characterized by relatively large differences in frequency distribution from race to race, and another, inter-race invariable characters, by little or almost no differences.

In the present article, discussion is focused on the former type of characters and special importance is attributed to the combination of those appearing common to the deciduous dentition of each component population of the Mongoloids. And then, the characteristics of the Ainu dentition will be analysed in the light of the Mongoloid dental complex.

\section{MATERIALS AND METHODS}

Materials used were composed mainly of plaster casts of dentition from Japanese, American Indians (Pima Indians), Alaska Eskimos, American Whites, American Negroes and Ainus. Part of the American Negroes and all materials of the Eskimos were skulls preserved by the Western Reserve University and the U.S. National Museum. The materials of the Ainu dentition were composed of the plaster casts from the livings of Shizunai district, southern part of Hokkaido, and the skulls collected by the late Professor Y. KOGANEI and now preserved by the Anatomy Department of University of Tokyo.

Crown characters in the deciduous dentition described in this paper were classified by comparing each tooth with the D-series plaques prepared for the deciduous dentition (HANiHARA, 1961). The detailed descriptions are given under the paragraphs for each character. In regard to the deciduous dentition combined sex-data were employed, since no difference between sexes was recognized in each crown character considered in this article. The observations were made, as a rule, on the right side teeth, the left side teeth having been taken into account only when the antimeres were badly damaged or lost. 
CROWN CHARACTERS COMPOSING THE MONGOLOID DENTAL COMPLEX IN THE DECIDUOUS DENTITION

\section{Shovel-shape in the deciduous upper incisors.}

The shovel-shaping in the permanent incisors has been well-known as one of those characters which show a remarkable racial difference. The data given by HRDLičKA (1920), WisSLER (1931), Goldstein (1948), Pedersen (1949), DAHLBERG (1949), OSCHINSKY and SMITHURST (1960), etc., show the same trends that the frequencies of this character are much higher in the Mongoloid populations than in the other.

The same is also true for the deciduous incisors. HRDLIčKA, for example, presented the frequencies of the shovelshaped deciduous incisors in the American Indians (tribes not specified). The occurrences of this trait are $60 \%$ for the upper deciduous incisors and 64\% for the lower ones which represent a striking contrast to those of the Whites.

In the present study the shovelshaping was dealt with only for the deciduous upper central and lateral incisors, because the trait in the lower teeth are usually so faint in its appearance that the inter-population difference is hardly to be shown.

The teeth were classified into two categories, no shovel-shape and shovelshape, by comparing each tooth to the Plaques D1 (for $\mathrm{i}^{1}$ ) and D2 (for $\mathrm{i}^{2}$ ). Both plaques illustrate four develop- mental stages of the shovel-shaping by attaching figures 0 through $3: 0$ for no-shovel, 1 for trace- or semi-shovel, 2 for true-shovel and 3 for strong shovelshape. In the present study, however, the teeth classified into stages 0 and 1 were combined and referred to a single category of no-shovel shape, and those classified into stages 2 and 3 were joined together to make another category of shovel-shape. The reason of such a simplification is based on the fact that the former group of teeth may, through genetical analyses, be regarded as noncarriers and the latter group as carriers of this trait (HANIHARA, 1965). The morphological differences between stages 0 and 1 as well as 2 and 3 may thus be considered as accidental variations caused by non-genetical factors.

The frequencies of the no-shovel and shovel-shaped teeth are shown in Table 1. One can easily find that three Mongoloid poulations show the same trend $i_{n}$ their much higher frequencies compared with those of the Whites and Negroes. The frequencies in the former populations take the lowest value in the deciduous upper central incisors of the Eskimos and the value of as high as $93.3 \%$ in the lateral incisors of the Japanese. In contrast to this, the Whites show virtually no case of the shovel-shape and the Negroes represent the figure of $15 \%$ at the most in the deciduous upper lateral incisors.

It is quite reasonable to state that the Mongoloid populations are charac- 
Table 1. Frequencies of the Crown Characters Composing the "Mongoloid Dental Complex" $(\delta+q$, in $\%)$

\begin{tabular}{|c|c|c|c|c|c|c|}
\hline \multirow{2}{*}{ Population } & \multicolumn{2}{|c|}{ Shovel-Shape } & \multirow{2}{*}{$\begin{array}{l}\text { Protostylid } \\
\qquad \mathrm{dm}_{2}\end{array}$} & \multirow{2}{*}{$\begin{array}{l}\text { Defl. Wrinkle } \\
\qquad \mathrm{dm}_{2}\end{array}$} & \multirow{2}{*}{$\begin{array}{l}\text { 6th Cusp } \\
\qquad \mathrm{dm}_{2}\end{array}$} & \multirow{2}{*}{$\begin{array}{c}\text { 7th Cusp } \\
\mathrm{dm}_{2}\end{array}$} \\
\hline & $\mathrm{di}_{1}$ & $\mathrm{di}^{2}$ & & & & \\
\hline Japanese & $76.6(124)$ & $93.3(163)$ & $44.7(152)$ & $71.6(201)$ & $36.9(92)$ & $73.7(156)$ \\
\hline Pima Indian & $61.6(78)$ & $64.3(98)$ & $89.0(118)$ & $84.3(115)$ & $36.8(117)$ & $72.9(118)$ \\
\hline Eskimo & $50.0(16)$ & $60.0(5)$ & $67.3(52)$ & $67.9(53)$ & $37.7(53)$ & $79.4(63)$ \\
\hline Am. White & $0.0(20)$ & $0.0(24)$ & $14.5(55)$ & 13. $0(54)$ & $7.3(55)$ & $40.7(54)$ \\
\hline Am. Negro & $10.0(10)$ & $15.0(22)$ & $17.0(47)$ & $19.1(47)$ & $14.0(50)$ & $46.8(47)$ \\
\hline Ainu & $50.0(4)$ & $66.7(9)$ & $45.5(22)$ & $70.0(20)$ & $23.8(21)$ & $71.4(21)$ \\
\hline
\end{tabular}

Figures in parentheses show numbers of individuals observed.

terized by their higher incidences of the shovel-shaped character in either the permanent or the deciduous incisors.

\section{Protostylid in the deciduous lower second molars.}

The term protostylid was first proposed by DAhlberg $(1945,1949,1950)$ for an extra cusp found on the buccal surface of the protoconid of the lower molars.

The original author reported extremely high frequencies of this extra cusp in the Pima Indians in comparison with the other populations in which it is only rarely observed, and later, SuzUki and SAKAI (1954) found fairly frequent appearance of this cusp in the lower molars of Japanese. These findings proved that the protostylid occurred very rarely in the dentition of modern man with the exception of some specific populations such as mentioned above.

In his studies of the deciduous dentition, however, HANIHARA (1956) reported that this extra cusp was frequently observed in the deciduous lower second molars, though it showed generally less degree of prominence compared with the permanent teeth. In Japanese, for instance, the frequency in the deciduous molars (47.7\%) exceeds twice of that observed in the permanent lower first molars (18.5\%).

Attributing the expression of this cusp to the particular gene combinations, Dahlberg (1949) suggested that potentialities for the cusp were probably universally present in man. If this hypothesis could be employed, the cusp seems to be a generalized character which is inhibited its manifestation by the secondary factors. The deciduous molars are likely less controlled by such inhibitors.

Plaque D8 shows seven stages of this formation appearing in the deciduous lower second molars. In this study, since no actual formation of the protostylid was in evidence in the first two stages, the remaining five stages were then combined as carriers of this trait.

As shown in Table 1, the protostylid has the same trend as the shovel-shaping in its much higher frequencies in the Mongoloids than in the Whites and 
Negroes. The extremely high incidence in the Pima Indians is very likely reflected in the same trend in their permanent molars.

\section{Deflecting wrinkle in the deciduous lower second molars.}

The deflecting wrinkle is one of the special formations of the median ridge of the metaconid. The ridge shows a stronger development in either its length or breadth and curves distalwards at the central part of the occlusal surface.

This character was first described by WEIDENREICH $(1937,1945)$ in his papers on Sinanthropus and Gigantopithecus, and subsequently, von KoENigSWALD (1952) drew attention to the deflecting wrinkle appeared in the deciduous lower molars in modern Javanese. In addition, the frequency distributions of this character in Japanese permanent molars were reported by Suzuki and SAKAI (1956a), and those in Japanese deciduous molars by HANiHARA (1956). The latter author and his co-workers (1964a) also gave detailed descriptions of varieties of this formation found in the permanent lower molars.

The frequencies of the deflecting wrinkle are also much higher in the deciduous lower second molars than in the permanent lower molars, and show distinct racial difference. The difference is especially striking when we compare the Mongoloid populations with the Whites and Negroes: the former is commonly characterized by their higher incidences and the latter by much lower ones. The contrast is even more remarkable than in the case of the protostylid (Table 1 ).

\section{Sixth cusp in the deciduous lower} second molars.

The 6th cusp is one of the extra cusps which appears occasionally between the entoconid and the hypoconulid. The incidence of this cusp in the permanent molars has been studied by several investigators and regarded as racial characteristic (HELlmAN 1928, Dahlberg 1945, etc:). Among the various discussions of this character, the following findings are of special interest as far as the present article is concerned: TRATMAN (1950) suggested a frequent appearance of the 6th cusp in the Mongoloids compared with the Indo-Europeans; and, Suzuki and SAKAI (1956b) reported that the frequencies in Japanese even exceeded those in Australian aborigines who had so far been considered to have the highest incidence.

Although only few data are available for the deciduous molars in recent man (JoRgensen 1956, HANihara 1956, HANiHARA $e t$ al. 1964b) the prevalence of the 6th cusp in the Mongoloid populations is more remarkable than in the case of the permanent teeth. The general trend of the percentile frequencies is just the same as the deflecting wrinkle. The three Mongoloid populations here presented show almost the same frequencies which form a striking contrast to the others (Table 1).

\section{Seventh cusp in the deciduous lower}




\section{second molars.}

The 7th cusp is another extra cusp which is located at the marginal border between the metaconid and the entoconid. This cusp was originally described by SELENKa (1898) who proposed the term tuberculum accessorium mediale internum, and reported many incidences by several subsequent authors in both fossil and recent primates including man. DE TERra (1905) reported frequencies of this cusp in the permanent lower molars of recent man and SuzukI and SAKAI (1956c) made a statistical investigation in Japanese.

On the other hand, as the other characters presented in this article, its appearance in the deciduous molars has so far been reported by few authors: RoBINSON (1956) described a case in the deciduous lower second molar of Australopithecus robustus from Kromdraai; JORGENSEN (1956) investigated the cusp in the same teeth of Dutch and Danes; and Hanihara and Minamidate (1965) made comparative studies of this cusp appeared in several populations.

In the present study Plaque D9 was used to warrant an objectivity of the classification. This plaque illustrates four developmental stages of the 7 th cusp arranged in serial order from absent, through trace and medium, to well-developed.

Table 1 shows frequencies of the individuals carrying this cusp who were counted regardless of the degree of development. All of the Mongoloid populations show the frequencies over $70 \%$ but, on the other hand, Whites and Negroes show those under 50\%. Here again, predominance of the former is proved as just in the other characters presented in this paper.

\section{SOME ASPECTS OF DENTAL COMPLEX IN THE DECIDUOUS DENTITION}

The crown characters in the deciduous dentition described in the previous chapter were selected in respect that they showed close similarities among the Mongoloid populations, and, at the same time, differed clearly from the others.

Although most of these characteristics have attracted our attention in their relatively high incidences in the permanent teeth of the Mongoloids, their predominance over the other racial stocks is more impressive in the deciduous dentition. This seems to depend on the fact that progressive reduction of dental characters has so advanced in the permanent dentition that most of the characters show less inter-population variabilities; or, on the contrary, the deciduous dentition retains more primitive characters that favor the comparative or phylogenetic studies of the human populations. In this connection, it should be noted that the similar extent of their prevalence could be attributed to the common origin of the component populations of the Mongoloid stock.

The population histories of the Mongoloid stock have recently come to attract attention of many anthropolo- 


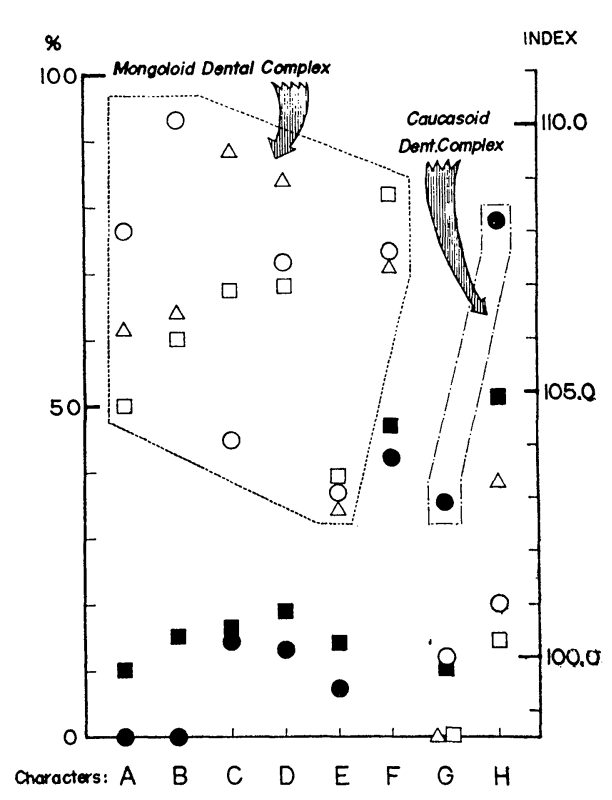

Fig. 1. Distributions of component characters of the Mongoloid and Caucasoid dental complexes.

Populations: $\bigcirc$ Japanese, $\triangle$ Pima Indian, $\square$ Eskimo, Am. White, Am. Negro

Characters: A Shovel-shape ( $\left.\mathrm{di}^{\mathrm{I}}\right)$, B Shovelshape $\left(\mathrm{di}^{2}\right)$, C Protostylid $\left(\mathrm{dm}_{2}\right)$, D Deflecting wrinkle $\left(\mathrm{dm}_{2}\right), \mathrm{E}$ 6th cusp $\left(\mathrm{dm}_{2}\right)$, F 7th cusp $\left(\mathrm{dm}_{2}\right)$, G Carabelli' $\mathrm{s}$ cusp $\left(\mathrm{dm}^{2}\right) \mathrm{H}$ Canine Breadth Index (dc).

gists who are especially interested in the arctic people. In regard to the dental anthropology, though a good number of studies were undertaken, further progress would be expected from re-evaluating their morphological characters in the light of the concept of the 'Mongoloid dental complex'.

The complex is, at present, confirmed to include at least five crown characters mentioned above for the deciduous dentition (Fig. 1). Some other characters will probably be added to this complex, as the studies on dental anthropology are advanced.

Apart from this, other combinations of dental characters will most likely be defined as the 'Caucasoid dental complex' which characterizes the Caucasoid populations. For instance, the frequencies of the Carabelli's cusp and the values of the canine breadth index in the deciduous dentition $(100 \times$ mesiodistal crown diameter of $\mathrm{d} c /$ mesiodistal crown diameter of $\mathrm{d} i^{1}$ ) represent peculiar figures to the Caucasoid populations.

As is well-known, the Carabelli's cusp appears much more frequently in the upper molars of the Caucasoids than in those of the other populations, and the difference is especially remarkable in the deciduous upper second molar. The canine breadth index in the deciduous dentition usually exceeds 105 in the Caucasoids but, in the other populations, it stays around or even below 100 (HANihara, 1966b). Thus, it might be supposed that these two characters form at least a part of the character combination that would be termed 'Caucasoid dental complex' (Fig. 1 and Table 2).

On the other hand, at least the deciduous dentition is concerned, the dental complex characterizing the Negro populations seems to be hardly definable, because the Negroes do not show any peculiar feature to their own teeth and usually represent intermediate patterns between the Mongoloids and the Caucasoids. 
Table 2. Frequencies of Dental Traits Characterizing the Caucasoid Population $(\hat{\delta}+q)$

\begin{tabular}{lcccc}
\hline Population & \multicolumn{2}{c}{$\begin{array}{c}\text { Carabelli's Cusp* } \\
\left(\mathrm{dm}^{2}\right)\end{array}$} & $\begin{array}{c}\text { Canine Breadth } \\
\text { Index (dc } u)\end{array}$ \\
\hline Japanese & $11.9 \%$ & $(185)$ & 101.0 & $(120)$ \\
Pima Indian & 0.0 & $(118)$ & 103.3 & $(98)$ \\
Eskimo & 0.0 & $(66)$ & 100.3 & $(14)$ \\
Am. White & 35.7 & $(56)$ & 108.2 & $(18)$ \\
Am. Negro & 11.8 & $(51)$ & 104.9 & $(10)$ \\
\hline Ainu & 16.0 & $(25)$ & 99.5 & $(5)$ \\
\hline
\end{tabular}

$*$ Pit type is not included.

\section{DECIDUOUS DENTITION IN THE}

\section{AINU}

In the light of the Mongoloid dental complex, the dental characters of the deciduous dentition of the Ainu were compared with those of the other populations.

The materials were composed of 25 individuals of almost full-blooded Ainu children, whose pedigrees were studied by the members of the Joint Survey of the Ainu made in early 1950's. Unfortunately, however, most of the front teeth were replaced by the permanent teeth. The crown characters were classified, by using the D-series plaques, in entirely the same way as in the case of the other populations. In Fig. 2 each character in the Ainu was plotted in accordance with their percentile frequencies and the value of the canine breadth index shown at the bottom of Tables 1 and 2 .

The higher frequencies of the dental characters composing the Mongoloid dental complex show an evident similarity of the Ainu to the Mongoloid

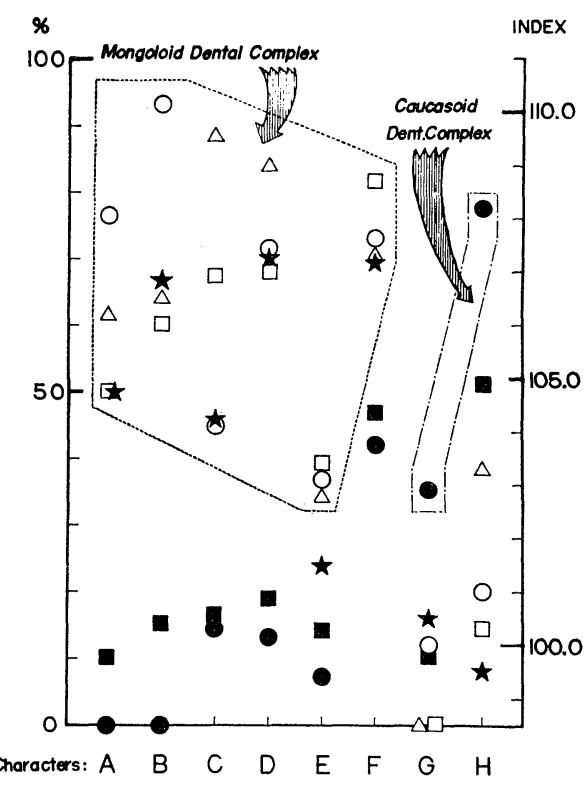

Fig. 2. Relationship between Ainu (indicated by black stars) and other populations (Symbols are the same as in Fig. 1).

populations, and the lower frequency of the Carabelli's cusp as well as lower value of the canine breadth index reveal the striking contrast between the Ainu and the White populations.

Further, what we can see from all the characters presented here is that 
the Ainu is closely related to the Japanese. The only exception is, though the number of materials is very small, the lower frequency of the shovel-shaped incisors. However, it is still within the range of variation among the Mongoloid populations.

As a whole, at least the deciduous dentition is concerned, the Ainu is closely related to the Mongoloids but differed clearly from the Caucasoids and the Negroids.

\section{PERMANENT DENTITION IN THE AINU}

Although any combination of characters that could be defined as the Mongoloid dental complex has not yet been confirmed to be present in the permanent teeth, the dental characters in these teeth might also provide a certain informations in regard to the population history of the Ainu.

I selected five crown characters which show a distinct contrast between the Mongoloids and the other populations. Additional reason why they were selected was that the reliable data have already been reported by several investigators.

First of all, I should like to discuss the shovel-shaped character in the permanent upper central incisors. This character has drawn attention of a number of investigators since almost 45 years ago. However, the classification that was originally given by HRDLIČKA (1920) and followed by most of the investigators gives not necessarily an adequate objectivity. The ideal method to measure the degree of development of this character was proposed by DAHLBERG and MiKkELSEN (1947). They used a modified bowley gauge and measured the depth of the lingual fossa. Following to this method, CARBONELL (1963) gave extensive data of the shovelshaped teeth found in several populations. However, her classification seems to be not quite satisfactory. For instance, she defined only those teeth with the lingual fossa of just $1 \mathrm{~mm}$. depth as the semi-shovel. Further, she classified the teeth with the depth less than $1 \mathrm{~mm}$. into trace-shovel category and gave no definition for no-shovel

Table 3. Classification of the Shovel-Shaped Incisors in Terms of the Depth of the Lingual Fossa.

\begin{tabular}{lcl}
\hline & $\begin{array}{c}\text { Depth of } \\
\text { Lingual fossa }\end{array}$ & \multicolumn{1}{c}{$\begin{array}{c}\text { Class of } \\
\text { Classification }\end{array}$} \\
\hline Method Suggested by CARBONELL (1963) & $1+\mathrm{mm}$. & \multicolumn{1}{c}{ Shovel } \\
& $1 \mathrm{~mm}$. & Semi-Shovel \\
& $1-\mathrm{mm}$. & Trace-Shovel \\
\hline Method Used in the Present Study & $1+\mathrm{mm}$. & Shovel \\
& $0.6-1.0 \mathrm{~mm}$. & Moderate-Shovel \\
& $0.0-0.5 \mathrm{~mm}$. & No-Shovel \\
\hline
\end{tabular}


category. We can easily imagine that there might be no incisor tooth with the completely flat lingual surface.

In this connection, I have re-classified the shovel-shaped character in terms of the depth of the lingual fossa (Table 3). In this classification, the moderate-shovel category includes both semi-shovel and trace-shovel categories so far been used. I should like to emphasize here that this method agrees satisfactorily with the classification without using the measurement of the depth of the lingual fossa.

Table 4 shows that the Ainu incisor teeth express much higher frequencies of the shovel-shaped character than those of the Caucasoids and come close to the Mongoloid populations. This trend is clearly seen in Fig. 3 that shows frequency distributions for each category of the shovel-shaped character, and it is of interest to note that the Ainu shows closer affinity to the Eskimo. The difference, though small, in

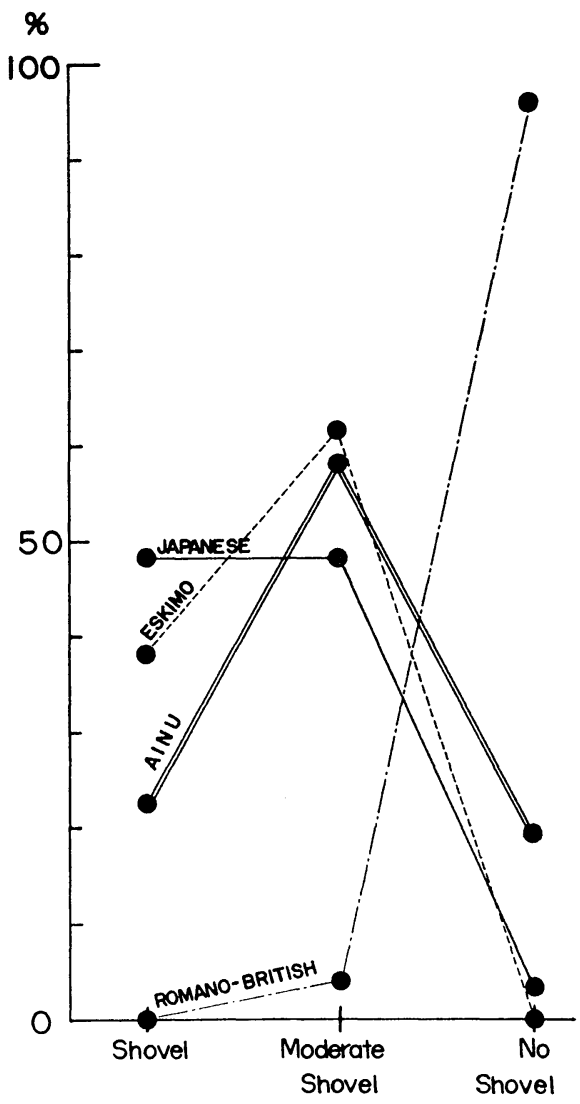

Fig. 3. Frequency distributions of each class of the shovel-shaping in the upper central incisor.

Table 4. Frequencies of Each Class of Shovel-Shaping in $\mathrm{I}^{1}$ (in \%).

\begin{tabular}{lccccc}
\hline \multicolumn{1}{c}{ Population } & $\begin{array}{c}\text { No. of } \\
\text { Individuals }\end{array}$ & $\begin{array}{c}\text { Shovel } \\
(1+\mathrm{mm})\end{array}$ & $\begin{array}{c}\text { Moderate-Shovel* } \\
(0.6-1.0 \mathrm{~mm})\end{array}$ & $\begin{array}{c}\text { No-Shovel } \\
(0-0.5 \mathrm{~mm})\end{array}$ & $\begin{array}{c}\text { Total of } \\
\text { Shovel }\end{array}$ \\
\hline Male: & & & & & \\
$\quad$ Ainu & 31 & 22.6 & 58.1 & 19.4 & 80.6 \\
$\quad$ Japanese & 60 & 48.3 & 48.3 & 3.3 & 96.7 \\
Female : & 13 & 30.8 & 61.6 & 7.7 & 92.3 \\
$\quad$ Ainu & 60 & 50.0 & 48.3 & 1.7 & 98.3 \\
$\quad$ Japanese & 100 & 0.0 & 4.0 & 96.0 & 4.0 \\
$\begin{array}{l}\text { Romano-British** } \\
\text { East Greenland }\end{array}$ & 76 & 38.1 & 61.7 & 0.0 & 100.0 \\
$\begin{array}{l}\text { Eskimo** } \\
\text { Japanese-Chinese- }\end{array}$ & 70 & 41.4 & 51.3 & 7.1 & 92.9 \\
Tibetan** & & & & & \\
\hline
\end{tabular}

* Carbonell's Semi- and Trace-shovel are combined.

** CARBonell, 1963. 
Table 5. Depth of Lingual Fossa in the Upper Central Incisor (in $\mathrm{mm}$.)

\begin{tabular}{ccccc}
\hline Population & $\begin{array}{c}\text { No. of } \\
\text { Individuals }\end{array}$ & Mean & Sx & $\mathrm{u}^{2}$ \\
\hline Male: Ainu & 33 & 0.83 & 4.6263 & 0.1446 \\
Japanese & 60 & 0.97 & 1.9760 & 0.0335 \\
Female: Ainu & 13 & 0.98 & 1.9948 & 0.1662 \\
Japanese & 60 & 1.10 & 4.9800 & 0.0844 \\
Pima Indian $(\hat{\delta})^{*}$ & 28 & 0.73 & - & - \\
\hline
\end{tabular}

* Dahlberg, 1949.

Table 6. Frequencies of the Protostylid in $M_{1}(\delta)$.

\begin{tabular}{lccc}
\hline \multicolumn{1}{c}{ Population } & $\begin{array}{c}\text { No. of Ind. } \\
\text { Observed }\end{array}$ & $\begin{array}{c}\text { No. of Ind. } \\
\text { with Protostylid }\end{array}$ & Frequency \\
\hline Ainu & 47 & 4 & $8.5 \%$ \\
Japanese & 60 & 4 & 6.7 \\
Pima Indian* & 100 & 21 & 21.0 \\
Am. White* & 50 & 1 & 2.0 \\
\hline
\end{tabular}

expression of the character between Ainu and Japanese is also reflected in the average values of the depth of the lingual fossa (Table 5).

Although no data have been unfortunately reported for the Caucasoid incisors, the average depth in the Ainu is supposed to be significantly larger than in the Caucasoids, because the value in the former is even larger than that in the Pima Indians in which the shovel-shaping is reported to be very remarkable. This seems to show that the development of the shovel-shaped character gives a reasonable basis to the Ainu to be included in the populations closely related to the Mongoloids.

The other characters selected for comparison are the protostylid, 6 th cusp and 7 th cusp in the lower first molars, and the Carabelli's cusp in the upper first molars.

The protostylid is especially frequently appeared in the Pima Indians, less in the Caucasoids. The frequency of this character in the Ainu exhibits a very close similarity to the Japanese and, on the contrary, a remarkable contrast to the Caucasoids (Table 6).

The frequencies of the 6 th cusp are strikingly higher in both Ainu and Japanese than in the other populations (Table 7). The same is the case in appearance of the $7 \mathrm{th}$ cusp which is more frequently appeared in the Japanese and the Australian aborigines compared with the Caucasoids. Although no comparative data are available for the other populations, the Ainu shows relatively closer affinity to the Japanese 
Table 7. Frequencies of the 6th Cusp in $M_{1}(\delta)$.

\begin{tabular}{lccc}
\hline Population & $\begin{array}{c}\text { No. of Ind. } \\
\text { Observed }\end{array}$ & $\begin{array}{c}\text { No. of Ind. } \\
\text { with 6th cusp }\end{array}$ & Frequency \\
\hline Ainu & 45 & 8 & $17.8 \%$ \\
Japanese & 60 & 13 & 21.7 \\
Am. Indian* & 100 & 6 & 6.0 \\
Eskimo* & 97 & 1 & 1.0 \\
White* & 98 & 0 & 0.0 \\
\hline
\end{tabular}

* Hellman, 1928.

Table 8. Frequencies of the 7 th Cusp in $M_{1}$ ( $\delta$ ).

\begin{tabular}{lccc}
\hline Population & $\begin{array}{c}\text { No. of Ind. } \\
\text { Observed }\end{array}$ & $\begin{array}{c}\text { No. of Ind. } \\
\text { with 7th cusp }\end{array}$ & Frequency \\
\hline Ainu & 47 & 2 & $4.3 \%$ \\
Japanese & 60 & 4 & 6.7 \\
Australian & - & - & 6.25 \\
Aborigine* & - & - & 1.48 \\
White* & & & \\
\hline
\end{tabular}

* DE TERRA, 1905.

in its frequency (Table 8).

The Carabelli's cusp appearing in the upper first molar shows the reverse trend to the other characters, that is, its frequencies are much higher in the Caucasoids than in the Mongoloids as is the case in the deciduous upper second molar. The percentile frequency in the permanent molar of the Ainu is even lower than that in the Japanese and shows a striking difference from the Caucasoids (Table 9). In addition to the other dental characters in the permanent teeth, the appearance of the Carabelli's cusp also proves a closer relationship of the Ainu to the Mongoloid populations.

As a whole, these five characters just mentioned above reveal the same picture that the Ainu usually stands close

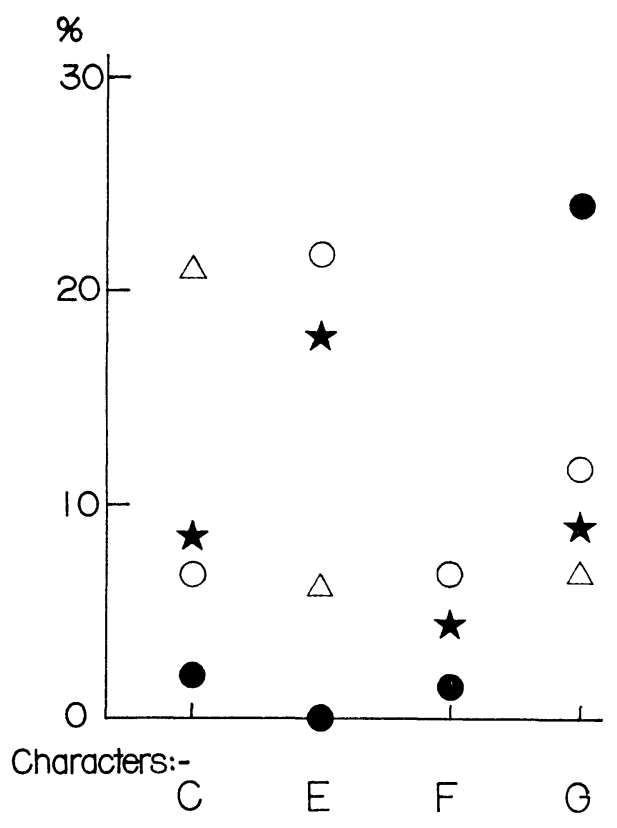

Fig. 4. Frequency distributions of dental characters in the permanent molars.

Populations: $\bigcirc$ Japanese, $\triangle$ Pima Indian, $\star$ Ainu, White

Characters: C Protostylid $\left(M_{1}\right)$, E 6 th cusp $\left(M_{1}\right), F$ th cusp $\left(M_{1}\right), G$ Carabelli's cusp $\left(\mathrm{M}^{1}\right)$. 
Table 9. Frequencies of the Carabelli's Cusp

(Tubercle Type) in $\mathrm{M}^{1}(\hat{\delta})$.

\begin{tabular}{lccc}
\hline Population & $\begin{array}{c}\text { No. of Ind. } \\
\text { Observed }\end{array}$ & $\begin{array}{c}\text { No. of Ind. } \\
\text { with C-Cusp }\end{array}$ & Frequency \\
\hline Ainu & 45 & 4 & $8.9 \%$ \\
Japanese & 60 & 7 & 11.7 \\
Japanese* & 1232 & 112 & 9.1 \\
Indian* & 1881 & 126 & 6.7 \\
European* & 1580 & 378 & 23.9 \\
American* & 429 & 125 & 29.1 \\
\hline
\end{tabular}

to the Mongoloids. This could be seen more apparently in Fig. 4 in which the Ainu occupies very close positions, especially to the Japanese.

\section{CONCLUSION}

Taking all the dental findings of the present study into account, we arrive, though tentatively, at the following conclusion: the dentition of the Ainu shows a close relationship to the Mongoloid populations, especially to the Japanese. This trend is evidently seen in either the deciduous or the permanent dentitions.

It might be of interest to introduce here that, in addition to the results given by Spuhler at the U. S.-Japan Anthropology Conference, 1966, the same conclusion has also been expressed by Kimura (1962), who studied the palm and finger print patterns of the Ainu. However, the minor differences such as revealed in expression of the shovelshaped character probably suggest, in combination with the other physical characters that differ from the surround- ing populations, that the population history of the Ainu might have some peculiar features to this population.

The studies on the Ainu dentition are still in process and we have recently collected some additional materials that were not taken into account in the present article. In addition to this, the group of the admixtures between Ainu and Japanese should be analysed in terms of the population genetics to find out the effects of hybridization on the dental characters. The studies in this respect are also being undertaken in our laboratory in parallel with the Japanese-American hybrid dentition on which I have been making investigation for more than ten years.

On the other hand, there have been some different interpretations in regard to the history of the Ainu. Based on similarities of the physical appearance, some authors attributed the origin of this population to the Caucasoids. However I am forced to emphasize that we should not overlook, at the present status of investigation, a large possi- 
bility of intrusion of the Mongoloid blood or genes into the Ainu as just supposed from what I discussed.

Discussions on the origin or the population history of the Ainu should be based on much more extensive data which include not only the characteristics of the skeletal and somatological characters but also those of the other characters such as palm and finger print patterns, dental traits, evidences of numerical taxonomy, and so forth.

\section{ACKNOWLEDGMENTS}

I wish to express my sincere thanks to Dr. F. J. OrLand and Dr. A. A. DahlBERG of the University of Chicago, Dr. T. D. Stewart of the U.S. National Museum, Dr. C. Francis of the Western Reserve University, and Dr. L. A. AlteMUS of the Howard University for kind permission to study the materials under their care. I am also indebted to Dr. S. SHimizu for co-operation in collecting the Japanese and Ainu materials.

\section{LITERATURE CITED}

CARBOnell, V.M. 1963: Variations in the frequency of shovel-shaped incisors in different populations. D. R. BROTHWELL (ed.): Dental Anthropology, Oxford: 211-234.

DAHLBERG, A. A. 1945: The changing dentition of man. J. Am. Dent. Assn., 32: 676-690.

- 1949: The dentition of the American Indian. Laughlin(ed.): Papers on the Physical Anthropology of the American Indian, The Viking Fund, Inc.: 138-176.

- 1950: The evolutionary significance of the protostylid. Am. J. Phys. Anthrop., n. s. 8: 15-25.

DAhlberg, A. A. and O. Mikikesen 1949: The shovel-shaped character in the teeth of the
Pima Indians, Ibid., n. s. 5: 234-235.

Goldstein, M.S. 1948: Dentition of Indian crania from Texas. Ibid., n. s. 6: 63-84.

LE Gros CLARK, W.E. 1955: The fossil evidence for human evolution. The University of Chicago Press.

HANIHARA, K.* 1956: Studies on the deciduous dentition of the Japanese-American hybrids. III. Deciduous lower molars. J. Anthrop. Soc. Nippon, 64 : 95-116.

1961: Criteria for classification of crown characters of the human deciduous dentition. Ibid., 69: 27-45.

1965: Some crown characters of the deciduous incisors and canines in JapaneseAmerican hybrids. Ibid., 72: 135-145.

1966a: Mongoloid deneal complex in the deciduous dentition, Ibid., 74: 61-72.

1966b: Relative size of the deciduous upper canine-A new racial character in the dentition. Ibid., 74: 9-18.

HANIHARA, K., T. KUWASHIMA and N. SAKAO 1964a: The deflecting wrinkle on the lower molars in recent Japanese. Ibid., 72: 1-8.

* 1964b: Intra-individual variations of crown characters in the molar teeth-On the 6th cusp and the deflecting wrinkle. J. Jap. Stomat. Soc., 13: 111-117.

HANiHARA, K.and T.Minamidate 1965: Tuberculum accessorium mediale internum in the human deciduous lower second molars. J. Anthrop. Soc. Nippon, 73: 9-19.

HellmaN, M. 1928: Racial characters in human dentition. Proc. Am. Phil. Soc., 67: 157 -174 .

HrdličKA, A. 1920: Shovel-shaped teeth. Am. J. Phys. Anthrop., 3: 429-465.

JORGENSEN, K. D. 1956: The deciduous dentition, a descriptive and comparative study. Acta Odont. Scand., 41, Suppl. 20.

KIMURA, K. 1962: The Ainus, viewed from their finger and palm prints. $Z$. Morph. Anthrop., 52: 176-198.

Koenigswarld, G.H.R. von 1952: Gigantopithecus blacki VON KOENIGSWALD, a giant fossil hominoid from the Pleistocene of Southern China. Anthrop. Pap. Am. Mus. 
Nat. Hist., 43, pt. 4.

OSCHINSKY, B. S. and R. SmithuRST 1960: On certain dental characters of the Eskimo of the Eastern Canadian Arctic. Anthropologia, n. s. 2: 105-112.

Pedersen, P.O. 1949: The East Greenland Eskimo dentition. Medelelser om Gronland, 142.

Robinson, J. T. 1956: The dentition of Australopithecinae. Transvaal Mus. Mem., 9.

SelenkA, E. 1898： Rassen, Schädel und Bezahnung des Orangutan. Menschenaffen (Anthropomorphae), pt. 1: 1-91, Wiesbaden. (Cited by WEIDENREICH, 1945.)

SuzUKI, M.and T.SAKAI* 1954: On the "protostylid" of the Japanese. J. Anthrop. Soc. Nippon, 63: 81-84.

*1956a: On the "deflecting wrinkle" in recent Japanese. Ibid., 65: 49-53.

— 1956b: On the "Dryopithecus pattern" in recent Japanese. Ibid., 64: 87-94.

*1956c: On the "tuberculum accessorium mediale internum" in recent Japane- se. Ibid., 64 : 135-139.

DE TERRA, M. 1905: Beiträge zu einer Ondontographie der Menschenrassen. Inaug. Diss. Phil., Zurich. (Cited by WEIDENREICH, 1945.)

TrATMAN, E. K. 1950: A comparison of the teeth of people, Indo-European racial stock with the Mongoloid racial stock. Dent. Rec., 70: 31-53, 63-88.

WEIDENREICH, F. 1937: The dentition of Sinanthropus pekinensis: A comparative odontography of the hominids. Palaeont. Sinica, n. s. D, No. 1.

1945: Giant early man from Java and South China. Anthrop. Pap. Am. Mus. Nat. Hist., 40, pt. 1.

Wissler, C. 1931: Observations on the face and teeth of the North American Indians. Ibid., 33, pt. 1.

(*Written in Japanese with English summary.)

(Received January 20, 1970)

歯における類モーコ形質群—とくにアイヌの歯について

\section{埴 原 和 郎 \\ 札蚂医科大学法医学教室}

私はさきに，モーコ系人種の乳歯に共通して，他の人種よりとくに多く現わ机る形質を分析し，乙れらをま

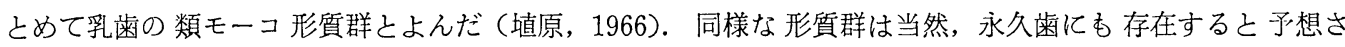
れるが，現在のととろ永久歯では，上顎切歯のシャベル型，下顎第 1 大曰歯の第 6 㕮頭，第 7 咬頭ならびに protostylid がこのような形質群の構成要素として考えられる. 同時に, 上顎第 1 大臼歯の CARABELLI 結 節は乳画と同様に Caucasoid に多く出現するので, てれはコーカソイド形質群とよばれるべきものと考えら れる。

ての論文では，乙のような形質群を基礎としてアイヌの菌冠形質の特徵を分析した．とくにシャベル型に関 しては従来の内眼的分類の代りに，切崡の舌側面䈑の深さを直接計測する方法を試みた．今回対象としたアイ 又の歯は少数ではあるが, 家系調査の結果, ほとんぞ純血と考えてよい集団である.

一般にアイヌでは, 乳䨑, 永久歯ともに類モーコ形質群の頻度が高く, とくに日本人(和人)に近い特徵を示 す.シャベル型の程度はやや弱いが，白人に比較するとかなり強いといえる。一才方, 白人に多い CARABELLI 結節はアイヌには少なく，乙の点でもアイヌはモーコ系人種に近い。アイヌの歯に関してはさらに資料を追加 しているので，今后は和人との混血集団に重点をおき，また資料数を增加して集団遺伝学的分析を行なう予定 である. 